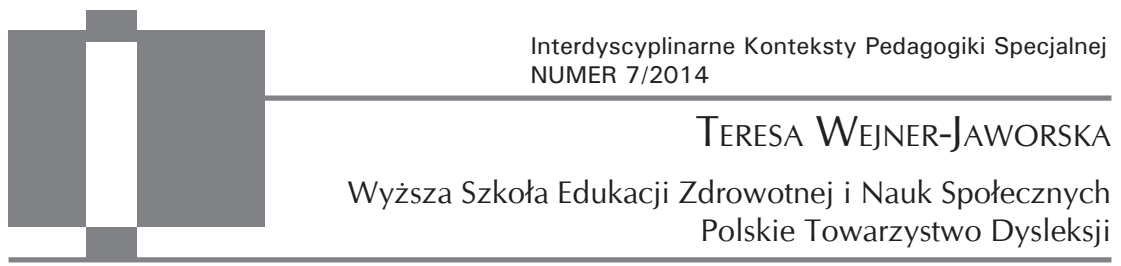

\title{
Inny, bo uzdolniony czy opóźniony?
}

\begin{abstract}
Авsтract: Wejner-Jaworska Teresa, Different, because of talented or retarded? [Inny, bo uzdolniony czy opóźniony?]. Interdyscyplinarne Konteksty Pedagogiki Specjalnej, nr 7, Poznań 2014. Pp. 27-39. Adam Mickiewicz University Press. ISBN 978-83-2322901-8. ISSN 2300-391X.
\end{abstract}

The article presents the problem of talented persons in the context of their own difficulties resulting from their understated self-esteem. The subject is presented as an examples of an adult and a child exposing the need of the early diagnosis of the child's ability. A proper and early diagnosis is the basis of comprehensive development, building an adequate and high self-esteem and prevention of social exclusion.

KEY WORDs: talented persons, self-esteem, diagnosis.

Bywają zaskoczeniem dla samych siebie, udręką dla najbliższych, a zarazem odkryciem i zdziwieniem, że potrafią więcej tam, gdzie inni nie potrafią. Nieoczekiwane sukcesy przeplatają się tym boleśniej z porażkami, gdy dotykają obszarów, które niszczą tę wyjątkowość, odbierając wiarę w siebie i uśredniając, bo takie jest oczekiwanie, by być w tzw. normie, czyli przeciętności. Dzieci uzdolnione i opóźnione, osoby wybitne i defektywne. Oto dwa przypadki: dorosłego i dziecka. 
Paweł, lat 24. Ukończył szkołę nauczany indywidualnie ze względu na fobię szkolną. Od wczesnego dzieciństwa nie miał kontaktów z rówieśnikami, nie uczęszczał do przedszkola. Nie miał kolegów, co skutkuje brakiem umiejętności, a nawet potrzeby nawiązywania relacji interpersonalnych z otoczeniem. Od kilku lat leczy się z powodu depresji. Obecnie jest studentem politechniki - studentem wybitnym, o twórczym podejściu do zagadnień napotykanych w toku studiów; średnia ocen 4,98.

Dostałem stypendium rektora, $i$ to wyższe (średnia na uniwersytecie powyżej 4,5, dokładnie 4,98) - mając zastrzyk gotówki przed świętami, wybrałem się do mojego ulubionego antykwariatu z fantastyka zapolować na biate kruki, które zawsze chciałem mieć - akurat trafitem na fenomenalną ksiażkę SF „Luna to surowa pani”, o kolonizacji księżyca (lata 60.) :- Poza tym wreszcie leki antydepresyjne zaczynaja pomagać (choć nie aż tak jakbym chciat), więc żyje już bez bólu psychicznego, choć wciaż demotywowany do robienia czegokolwiek. Mimo to jest lepiej, a będzie jeszcze lepiej! :-)

Paweł zgłosił się do Polskiego Towarzystwa Dysleksji, szukając pomocy w problemach z czytaniem. Chce się dowiedzieć, czy na jego problemy nakłada się również dysleksja.

Czytanie jest dla mnie problemem, w dodatku bardzo ekspansywnie rozwijajacym się. Doszedtem do takich absurdów na tym polu, że nie jestem w stanie zrobić korekty tekstu, który napisatem chwile wcześniej (pisanie jest dużo prostsze!), albo przeczytać ze zrozumieniem polecenia w zadaniu z matematyki - nie odciska się dostatecznie głęboko w pamięci. Rozwiąując dane zadanie, zdarza mi się zgadywać, o co mnie pytaja na podstawie udostępnionych danych. Doświadczenie z konkursów robi swoje i nadal nic nie zawalam na studiach, ale musze przyznać - zaczynam być sytuacją przerażony. Trzymam się jeszcze idei, że może zwyczajnie niedowidze, jutro idę do okulisty - okulary to wciąż nowość dla mnie i nie bardzo ogarniam, po czym poznać, że powinienem je wymienić.

Badanie inteligencji w skali Wechslera II=138; percepcja słuchowa: wynik bardzo wysoki, wzrokowa również. W trakcie diagnozy ujawniają się problemy z wyobraźnią przestrzenną oraz figuratyw- 
ną, np. wyraz „czerwona róża” nie kojarzy mu się z kwiatem, lecz tylko ze słowem i jego wyuczonym znaczeniem.

Rozpoczynamy terapię indywidualną. Paweł chętnie uczestniczy w spotkaniach i podkreśla, że bardzo ich potrzebuje. Wiele rozmawiamy i poszukujemy najbardziej skutecznych metod. Podczas relaksacji nie potrafi relaksować się przy zamkniętych i nie jest w stanie „zobaczyć" obrazów sugerowanych podczas wizualizacji. Praca na lustrzanych neuronach daje pozytywne efekty w obszarach związanych z kontaktami interpersonalnymi.

Paweł odnosi jednak spektakularny sukces:

Dostatem maila z uczelni, iż japońska firma Rococo prowadzi rekrutacje wśród studentów studiów inżynierskich. Przedmiotem rekrutacji byty dwuletnie studia magisterskie na Wasada University w Japonii na ich koszt $i$ kontrakt jako programista na kolejnych pięć lat po ukończeniu nauki. Stwierdziłem, że w sumie niczym nie ryzykuje, a mogę się sprawdzić, więc na spotkanie poszedtem. Po prezentacji (po angielsku) profilu firmy i opisu różnic $w$ studiach w Japonii (m.in. ich rok akademicki zaczyna się w kwietniu) dostaliśmy test kompetencji językowych, a następnie właściwy test IT. Rozwiazałem go jako pierwsza osoba na sali; na 22 pytania musiatem strzelać we 2, a w dalszych 5 nie bytem $w$ 100\% pewien, w pozostatych nie miatem żadnych watpliwości. Oddałem test, podziękowatem i wyszedtem. Sprawdzitem później w domu, okazało się, że w obu pytaniach, w których strzelatem, strzelitem celnie. Pięć dni później zadzwonit telefon, na wyświetlaczu numer kierunkowy z Japonii. Umówiłem się na spotkanie rekrutacyjne (ang. interview), ciekaw sytuacji. Spotkanie zaczęto się jednak od totalnego rozbrojenia mnie - przedstawiciel firmy powiedziat, że wykonywali te testy na uczelniach w Krakowie, Warszawie, Poznaniu $i$ Łodzi i mój wynik byt najwyższy w kraju, w catym teście miałem jeden btad. Rozmowa sprowadzita się do moich pasji, zainteresowań, specjalizacji $i$ tego, kiedy chciałbym zaczać. Ponieważ jestem dopiero na drugim roku, a program w teorii powinien być przeprowadzony na trzecim, stanęto na tym, że mam rok, by się zastanowić, czy chce jechać do Japonii.

Nie pojechał, odmówił, bo miał obawy, że to się nie powiedzie. Boi się rozczarowania i przegranej. Nie jest gotów na taką decyzję.

Jest to o tyle zabawne, że nie dalej jak dwa tygodnie wcześniej powiedziałem psychologowi w ramach terapii, że dawno nie miatem dużego osiagnięcia (w zwiazku 
z moją samoocena) i brakuje mi jakiegoś potwierdzenia z zewnątrz mojej wartości intelektualnej. Tzn. tak, ja wiem, że jestem zdolny i mam ogromne możliwości, ale $w$ momencie gdy stabsi znajomi coś osiągaja, a ja nie, moja samoocena zaczęła się pogarszać.

Otrzymał potwierdzenie swojej wartości intelektualnej i na tym poprzestał. To zresztą nie jedyne osiągnięcie Pawła w ostatnim czasie:

Zajątem też 17. miejsce w Polsce (na ok. 700) w teście rekrutacyjnym, dla odmiany, do praktyk wakacyjnych $w$ Microsoft, Redmond w USA. To jednak nie byto aż tak budujace jak kwestia japońska:-)

Nie pojedzie, bo nie wierzy, że potrafi się tam odnaleźć. Nie chce ryzykować przegranej. Lęk przed niepowodzeniem, porażką powoduje postawę wycofującą się. Czy uda się pomóc Pawłowi, aby mógł wykorzystać swój wyjątkowy potencjał i tym samym poprawić swą niską samoocenę? Lęk towarzyszący podjęciu decyzji jest u niego związany z myślami, „co się może wydarzyć”, choć sam nie potrafi tego określić. W związku z tym nie wie, co robić, i ma trudności z reagowaniem. Behawioralne składniki lęku mogą obejmować ucieczkę lub walkę. U Pawła źródłem leku są nierealne zagrożenia. Jest to mechanizm ucieczki o podłożu patologicznym, gdy zagrożenie jest nieokreślone, niewspółmierne bądź irracjonalne ${ }^{1}$.

Rozpoczyjąc terapię, opieram się na teorii, według której połączenie budzących obawy sytuacji ze stanem odprężenia wzbudza nowe skojarzenia, które hamują powstawanie reakcji lękowej. Przyjmuję, że sposobem na pokonanie lęku jest stawienie mu czoła. Posługuję się metodą stopniowania kontaktu. Takie działania mają spowodować wzrost poczucia pewności, że poradzi on sobie z trudną konfrontacją. Szczególnie skuteczne w terapii lęku okazują się trzy terapie behawioralne: systematycznego odwrażliwiania (desensytyzacji), ekspozycji i modelowania ${ }^{2}$.

1 A.A. Lazarus, A.M. Colman, Psychopatologia, Zysk i S-ka, Poznan 2001, s. 13-38.

2 M.E.P. Seligman, E.F. Walker, L.D. Rosenhan, Psychopatologia, Zysk i S-ka, Poznań 2003. 
Terapia trwa, lecz samoocena Pawła wciąż pozostaje niska. Wczesne doświadczenia z dzieciństwa związane z trudną sytuacją rodzinną oraz niesprzyjająca sytuacja edukacyjna u progu szkoły, nieakceptacja i poczucie odrzucenia uaktywniły się $w$ postaci fobii szkolnej. Niedostatek interakcji z otoczeniem i brak kontaktów $\mathrm{w}$ grupach społecznych spowodowały izolację. $\mathrm{W}$ kolejnych latach ujawniła się depresja, której Paweł nie potrafi pokonać mimo terapii farmaceutycznej i pomocy neurologiczno-psychiatrycznej. Od lat czuł się „porzucony” przez społeczeństwo, trwał w społecznej izolacji, czując się Innym.

Drugim analizowanym przypadkiem jest dziecko.

Jaś ma niespełna 6 lat (dokładnie 5 lat i 8 miesięcy), uczęszcza do "zerówki", po raz pierwszy mając kontakty z rówieśnikami. W grupie nie znajduje jednak kolegów i czuje się odrzucany, tym bardziej że ma wadę mowy, nie potrafi „ładnie rysować” ani nie ma innych osiągnięć, jakich oczekuje się w „zerówce”. Wykazuje zaniżoną samoocenę.

Matka chłopca zgłosiła się do Polskiego Towarzystwa Dysleksji z obawą, że jej syn jest dzieckiem z grupy ryzyka dysleksji. Sama jest bowiem osobą dyslektyczną. Jako uczennica miała w szkole z tego powodu wiele trudności i gdyby nie opinia z poradni psychologiczno-pedagogicznej, nie zdałaby matury. Matka obawia się, że że Jaś może mieć podobne problemy w szkole jak ona i nie podoła wymaganiom szkolnym. Gdy trafi do szkoły rejonowej, zostanie wtłoczony w uśredniony program nauczania, może okazać się opóźniony, a ona dostrzega w dziecku wyjątkowość. Gdyby skontaktowała się z poradnią psychologiczno-pedagogiczną i jasno przedstawiła swoje spostrzeżenia na temat syna, wydałaby się niewiarygodna, bo dziecko wykazuje pewną niedojrzałość.

Z wizyty Jasia w gabinecie terapeutycznym Polskiego Towarzystwa Dysleksji wynika, że jest on nieśmiały i małomówny, ale po nawiązaniu relacji mówi chętnie i ciekawie. W badaniu KSI (krótkiej skali inteligencji) osiągnął wynik wysoki. Poproszony o narysowanie postaci człowieka ma problemy - nie potrafił narysować pełnej postaci ludzkiej, czyta słabo, pisze również tylko drukowanymi litera- 
mi, ma problemy z rozróżnianiem stron - lateralizacja skrzyżowana (lewe oko i prawa ręka), motoryka mała słabo rozwinięta w stosunku do norm dla wieku 6 lat.

Ale gdy Jaś po badaniu w gabinecie zobaczył profesjonalną trąbkę, bardzo się nią zainteresował i ku zaskoczeniu terapeutki i swojej mamy zaczął na niej grać. Nigdy wcześniej nie widział z bliska takiego instrumentu, tylko na obrazkach. Wydawanie dźwięków sprawiało chłopcu widoczną radość. Grał z pasją, bez oznak zmęczenia i bez wysiłku potrafiąc wydobywać z instrumentu dźwięki.

Takich dzieci jak Jaś jest więcej - są one często zaskoczeniem dla siebie samych i dla rodziców. Są to dzieci zarazem uzdolnione i opóźnione, wybitne i defektywne, przy czym trzeba odróżnić pojęcie „zdolny” od „uzdolniony”.

Zdolny to taki uczeń, który wykazuje wysokie kompetencje poznawcze, takie jak: logiczne myślenie i koncentracja uwagi, które dają się zmierzyć testami. Uzdolniony to uczeń wybijający się kierunkowo, np. muzycznie, matematycznie, lingwistycznie czy plastycznie.

Rozwój zdolności, czyli mocnych stron jednostki, stanowi podstawę budowania poczucia własnej wartości. Odkryte uzdolnienia mogą być predyktorami osiągnięć i sukcesu szkolnego, a nawet życiowego ucznia. Świadomość, że w jakiejś dziedzinie jesteśmy bardziej sprawni od innych, podnosi samoocenę.

Badania w szkole muzycznej potwierdziły wybitne uzdolnienia muzyczne dziecka. Od nowego roku szkolnego Jaś rozpocznie naukę jako 6-latek w szkole muzycznej. Wierzę, że twórczego potencjału tego dziecka szkoła muzyczna nie zaprzepaści.

Jak zatem działać, aby zapewnić najlepsze efekty uczenia?

Z badań J. Hattiego ${ }^{3}$ wynika, że najważniejszym czynnikiem warunkującym powodzenie w nauce jest samoocena, czyli subiektywne spojrzenie na własną osobowość. A przecież wielu z uzdolnionych

${ }^{3}$ John Hathie jest profesorem w Auckland University. Przez 15 lat prowadził badania nad czynnikami mającymi największy wpływ na poprawę wyników nauczania. W tym czasie dokonał 800 analiz badań edukacyjnych przeprowadzonych na 200 mln uczniów, które objęły tysiące rozmów indywidualnych, trwających po 5 minut. 
to również uczniowie o zaniżonej samoocenie. Jesteśmy jednostką psychosomatyczną i środowisko wywiera ogromny wpływ na nasz rozwój. To, jak odczuwamy, dokonuje się w naszym mózgu. Zaburzenie poczucia własnej wartości powstaje zazwyczaj pod wpływem komunikatów podważających wartość dziecka, jakie dostaje ono od osób znaczących, którymi są dla niego rodzice, nauczyciele i rówieśnicy. Zdaniem B. Hornowskiego ${ }^{4}$ uzdolnienia rozwijają się w zależności od warunków społeczno-historycznych, w jakich żyjemy. Jest to szczególnie widoczne u dziecka, którego indywidualność wynika z niepowtarzalności klimatu rozwojowego, czynników środowiskowych, warunków osobniczego rozwoju. Osoby uznawane za bardziej inteligentne wykazują ogólnie większą sprawność umysłową i lepiej funkcjonują w nowych sytuacjach. Istotne są także czynniki wpływające na satysfakcję jednostki, jej aktywność intelektualną, społeczną i emocjonalną.

W przypadku Jasia symptomy niskiej samooceny można było zaobserwować jeszcze przed podjęciem nauki szkolnej. Zdrowa samoocena to stan, w którym akceptujemy zarówno swoje zalety, jak i wady. W relacjach z innymi ludźmi porzucamy schemat lepszygorszy. Będąc świadomi tego, że każdy z nas jest inny, w tej różnorodności wszyscy jesteśmy równi.

Z kolei wysokie IQ u Pawła nie wystarcza, by dobrze radził sobie w codziennym życiu. Potwierdzają to badania psychologów, że zależność między inteligencją (mierzoną testami inteligencji) a radzeniem sobie $\mathrm{w}$ dorosłym życiu nie jest oczywista. Poziom zdolności umysłowych pozwala przewidzieć powodzenie w szkole i w czasie studiów, ale nie warunkuje dobrego przygotowania do życia i przyszłej pracy zawodowej5.

4 B. Hornowski, Rozwój inteligencji i uzdolnień specjalnych, WSiP, Warszawa 1986, s. 182.

${ }^{5}$ Poglądy na temat istoty inteligencji i struktury zdolności były przedmiotem rozważań i wielu publikacji psychologicznych - od F. Galtona, późniejszych dokonań Ch. Spearmana, A. Bineta, R.B. Cattella, J.P. Guilforda, aż po koncepcje J. Piageta, R. Sternberga i H. Gardnera. 
Zdaniem E. Nęcki ${ }^{6}$ sprawność intelektualna jest powiązana z dynamiką procesów poznawczych, dzięki większej pojemności pamięci krótkotrwałej oraz większym zasobom uwagi. Może to dotyczyć nie tylko tych dwóch czynników, ale również innych, współwystępujących z nimi, np. stopnia pobudzenia intelektu, posługiwania się strategiami czy skutecznego radzenia sobie z nowymi, trudnymi zadaniami rzeczywistymi lub szkolnymi.

Ogromną rolę odgrywają tu inteligencja emocjonalna ${ }^{7}$ i praktyczna ${ }^{8}$, kiedy uczeń musi umieć współżyć i współdziałać z innymi. Jednak za proces twórczy odpowiadają: wyobraźnia, intuicja i myślenie dywergencyjne. Wyobraźnia i myślenie obrazowe to proces psychiczny polegający na przetwarzaniu posiadanych obrazów i wytwarzaniu nowych obrazów psychicznych. Intuicja zaś to nieświadoma inteligencja, która prowadzi do wiedzy bez rozumowania i wnioskowania. Myślenie dywergencyjne to z kolei takie myślenie, które dla jednego problemu poszukuje wszystkich możliwych rozwiązań. Wyróżnia się trzy jego cechy: płynność (liczba pomysłów), giętkość (różnorodność pomysłów), oryginalność (pomysły niecodzienne, zaskakujące, niebanalne, rzadkie). Umiejętność rozwiązywania zadań dywergencyjnych jest kojarzona od połowy XX wieku z myśleniem twórczym, rozpropagowanym przez amerykańskiego psychologa J.P. Guilforda9 .

Współczesne badania nad różnicami indywidualnymi i uzdolnieniami przyczyniły się do lepszego poznania procesów poznawczych i afektywnych oraz wzajemnego oddziaływania czynników emocjonalnych i motywacyjnych na rozwój intelektualny człowieka.

Rozwijając zdolności twórcze, należałoby skupić się na zadaniach dywergencyjnych, które są otwarte na myślenie twórcze w zadaniach, kiedy występuje wielość możliwych rozwiązań. Z takimi zadaniami

${ }^{6}$ E. Nęcka, Psychologia poznawcza, Wydawnictwo Naukowe PWN, Warszawa 1994, s. 297-299.

7 D. Goleman, Inteligencja emocjonalna, Media Rodzina, Poznań 1997.

8 R.J. Sternberg, Human abilities: An information-processing approach, „Developmental Psychology" 1985, nr 24, s. 646-653.

9 J.P. Guilford, Natura inteligencji człowieka, PWN, Warszawa 1978. 
spotykamy się w codziennym życiu. Niewielka część problemów ma zaś charakter zadań konwergencyjnych, które opierają się na inteligencji. Niestety, w szkołach dalej ćwiczymy tylko te zadania.

Dociekania nad inteligencją człowieka skupiają się wokół alternatywy: genetyka czy środowisko. Badania R.L. Jirtle'a i R.A. Waterlanda ${ }^{10}$, wykazały, że informacje napływające z zewnątrz aktywują określone geny. Geny są włączane, wyłączane lub modyfikowane przez okoliczności życiowe i otoczenie: przez to, co jemy, kim się otaczamy i jak prowadzimy życie ${ }^{11}$. Zmiany oraz ekspresja lub wyciszenie danego genu zachodzą wskutek środowiskowych czynników stresowych. Dieta, jakość powietrza i wody, klimat emocjonalny panujący w rodzinie, kontakty ze środowiskiem społecznym, poczucie sukcesu w nauce, styl życia przyczyniają się do tego, jakimi osobami jesteśmy ${ }^{12}$.

Od 2013 r. uczeń zdolny zaczął być dostrzegany w obszarze edukacyjnym jako uczeń wymagający indywidualnego podejścia. Ministerstwo Edukacji włączyło uczniów zdolnych do grona uczniów ze specjalnymi potrzebami edukacyjnymi (mają oni prawo korzystać z pomocy psychologiczno-pedagogicznej) i ogłosiło, że jest nastawione na pracę z uczniem zdolnym. Takie też są zadania stawiane przed szkołami i poradniami psychologiczno-pedagogicznymi. Problem w tym, że w poradniach brakuje specjalistów ukierunkowanych na pracę z uczniem zdolnym. Z sondażu przeprowadzonego w 25 poradniach psychologiczno-pedagogicznych wynika, że niewielu jest specjalistów przygotowanych do pracy z dzieckiem zdolnym oraz do współpracy ze szkołami w tym obszarze.

Są jednak początki wspierania uczniów zdolnych w procesie edukacyjnym. W Łodzi z nastawieniem na kreatywne działania, z inicjatywy międzyporadnianego zespołu poradni psychologiczno-pedagogicznych w Łodzi, w roku szkolnym 2013/2014 przygotowa-

${ }^{10}$ Jednym z pierwszych badaczy tego tematu był B. Lipton, The Biology of Belief, Hay Hause, New York 2008.

${ }^{11}$ L. McTaggart, Więź. Odkryj połaczenie między Tobą a resztą świata, Studio Astropsychologii, Białystok 2013, s. 57.

12 Ibidem, s. 58. 
no program pt „Mój zdolny uczeń”. Jego celem było przeszkolenie szkolnych koordynatorów ds. uczniów zdolnych. W każdej ze szkół wytypowano od jednej do trzech takich osób. Na szkolenia w Łodzi zgłosiło się 94 nauczycieli z 45 szkół podstawowych oraz 27 nauczycieli z gimnazjów. Następnie każda z poradni psychologiczno-pedagigicznych realizowała trzy szkolenia dla koordynatorów ds. pracy z uczniem zdolnym ze szkół swojego rejonu. Tematyka spotkań obejmowała:

a) zdolnosci, uzdolnienia, talenty i sposoby ich rozpoznawania,

b) tworzenie klimatu sprzyjającego rozwojowi u uczniów potencjału w zakresie różnych uzdolnień,

c) wspieranie rozwoju społeczno-emocjonalnego, współpraca z rodzicami, rola koordynatora szkolnego ds. wspierania uczniów zdolnych.

Niestety, po roku nie było już chętnych do kontynuowania spotkań w poradniach. Wyjątkiem była poradnia Bałuty 1, gdzie odbyło się jeszcze 5 spotkań z 12 nauczycielami z 9 szkół (6 podstawowych i 3 gimnazjów). Tematyka spotkań w bieżącym roku szkolnym dotyczyła neurodydaktyki, form i metod pracy z uczniem zdolnym, rozwijania kreatywnego myślenia oraz współpracy z rodzicami.

Jak bardzo trudny jest to obszar działań dla nauczycieli, świadczy przykład nauczycielki uczestniczącej w szkoleniach, która prosiła, by nie zgłaszać jej do dyrekcji szkoły, bo będzie musiała podjąć w szkole takie nowatorskie działania, otrzymując dodatkowe zadanie od dyrektora szkoły, a ona nie jest do tego gotowa psychicznie ani merytorycznie. Nauczyciele nie wiedzą, jak się ustosunkować do innowacji i raczej są niechętni wprowadzaniu ich w swoich szkołach. Należałoby więc rozpocząć w tym obszarze "pracę u podstaw”. Jak bowiem działać, gdy obecna szkoła uczy dziecko działań, które mają się podobać nauczycielowi bądź sprawdzać się w testach egzaminów zewnętrznych. Taka postawa nie uczy myślenia, zwłaszcza myślenia niestandardowego, kreatywnego, a także nie pozwala rozwijać się dziecku utalentowanemu, które ma problemy z dostosowaniem się do wymogów szkoły, gdzie nie ma miejsca na talenty, a liczy się przeciętność. 
Zajęcia z wielu przedmiotów prowadzone są zwykle tak, że daje się uczniowi do zrozumienia, iż rozwiązywane zadanie ma tylko jedną poprawną odpowiedź, co często nie jest prawdą. Stosowanie testów i sprawdzianów, ale również podręczników zawierających klucz odpowiedzi sprawia, że uczeń jest przekonany o istnieniu jedynej słusznej odpowiedzi. Bez klucza odpowiedzi uczniowie nie potrafią sobie radzić, bo nie nauczono ich kreatywnego podejścia do zadań.

Nauczyciel, który jest zwykle autorytetem dla uczniów, stwierdzając u dziecka brak talentu do danego przedmiotu, może spowodować blokadę w nauce tego przedmiotu. Zdaniem M. Pasterskiego ${ }^{13}$ błędem powtarzanym przez wielu pedagogów jest podział umiejętności uczniów według pewnych schematów, np. tego, że dziecko może być obdarzone tylko jednym talentem: artystycznym, matematycznym albo humanistycznym. Często jednak dzieci mają umiejętności z różnych dziedzin. Tymczasem system edukacji zamiast uczyć dzieci łączyć różne zdolności, ukierunkowuje je na zdobywanie biegłości tylko w jednej dziedzinie.

W edukacji często stosuje się też hierarchię przedmiotów, z naciskiem na przedmioty ścisłe, bagatelizując tym samym np. talenty artystyczne uczniów. Gdy uczeń zostanie sklasyfikowany jako umysł ścisły, nabiera przekonania o braku zdolności w innych dziedzinach (humanistycznych lub artystycznych) i traci nimi zainteresowanie. W taki sposób przyczyniamy się do tworzenia „umysłów ściśniętych", sprowadzając naukę do jednotorowego procesu, w którym każdy uczeń jest uczony i oceniany w taki sam sposób. Nie dostrzega się odmienności dzieci, ich własnego sposobu uczenia się, różnorodnych zainteresowań, pasji i marzeń, bo każdy uczeń realizuje naukę $\mathrm{w}$ systemie, który nie uwzględnienia jego odmienności. Zalecenia Ministerstwa Edukacji dotyczące indywidualizacji nauczania $\mathrm{w}$ aktualnym systemie edukacji są prawie niemożliwe do realizacji. W obecnych szkołach dzieci się nudzą i tracą zapał do nauki, bo na-

${ }^{13}$ http:// michalpasterski.pl/2014/04/13-bledow-polskiego-systemu-edukacji [6.04.2015]. 
uczyciele w większości nie potrafią przekazywać im wiedzy w interesujący sposób, choć zdarzają się też nauczyciele z pasją, ale zwykle są to wyjątki.

A gdyby tak wybrać drogę ukierunkowaną na realizację potrzeb i aspiracji dziecka, tworząc warunki do jego twórczego rozwoju, dostarczając wiedzy, kształtując umiejętności, pozwalając mu na zdobywania nowych doświadczeń i odkrywanie zdolności? Warto wypracować strategie otwartych działań nastawionych na róznorodne potrzeby dziecka i tak zorganizować proces uczenia się i nauczania, by rozbudzić wewnętrzną aktywność ucznia. Zdaniem D. Klus-Stańskiej „nauczanie powinno polegać na samodzielnym stosowaniu przez uczniów metody naukowej, za pomocą której uczeń musi sam uruchamiać procesy poznania"14.

To twórcze zdobywanie nowych doświadczeń charakteryzuje Jasia i wiele innych dzieci przed podjęciem nauki szkolnej - oby nie zakończyło się w zetknięciu ze szkołą. Badania przeprowadzone w ostatnich latach wskazują na możliwość rozwijania myślenia inteligentnego i kreatywnego dzieci w taki sposób, jak uczy się czytania, pisania, rozumowania, matematyki czy muzyki. Służą temu odpowiednie zadania, ćwiczenia i treningi, których skuteczność zależy od wielu czynników, m.in. momentu rozpoczęcia ćwiczeń, ich intensywności, motywacji dziecka do pracy, współpracy z rodziną.

Istotna $\mathrm{w}$ tym procesie jest zmiana znaczenia błędów uczniowskich, które „nie tylko tracą swój złowieszczy charakter, ale stają się »tworem ", na który jest dydaktyczne zapotrzebowanie"15. Uczeń powinien wiedzieć, że $\mathrm{w}$ trakcie nauki ma prawo do popełniania błędów, za które nie może być karany złą oceną. Powinien otrzymać informację, z której jasno wynika, co już potrafi, a co musi zrobić, by było lepiej. Będzie to dla niego motywacją do dalszego działania.

Naszym zadaniem jest wspomagać rozwój dziecka, a jeżeli tego nie potrafimy, to przynajmniej nie ograniczajmy jego rozwoju. Jak

${ }^{14}$ D. Klus-Stańska, Dydaktyka wobec chaosu pojęć i zdarzeń, Żak, Warszawa 2010, s. 312.

${ }^{15}$ D. Klus-Stańska op. cit., s. 340. 
powiedział Jose da Silva: „Człowiek rodzi się genialny, a potem idzie do szkoły".

Może znów rewolucja edukacyjna zostanie zainicjonowana przez jezuitów, o czym świadczą wprowadzane przez nich obecnie innowacje w katalońskich szkołach. To oni byli w XVII wieku w hiszpańskim imperium potęgą edukacyjną ${ }^{16}$.

\section{Bibliografia}

Goleman D., Inteligencja emocjonalna, Media Rodzina, Poznań 1997.

GUILFORD J.P., Natura inteligencji człowieka, PWN, Warszawa 1978.

HornowsKi B., Rozwój inteligencji i uzdolnień specjalnych, WSiP, Warszawa 1986.

KLus-StańsKa D., Dydaktyka wobec chaosu pojęć i zdarzeń, Żak, Warszawa 2010

Lazarus A.A., Colman A.M., Psychopatologia, Zysk i S-ka, Poznan 2001.

LiPTON B.H., The Biology of Belief, Hay Hause, New York 2008.

McTaggart L., Więź. Odkryj połączenie między Tobą a reszta świata, Studio Astropsychologii, Białystok 2013.

NęCKA E., Psychologia poznawcza, Wydawnictwo Naukowe PWN, Warszawa 1994.

Seligman M.E.P., Walker E.F., Rosenhan L.D., Psychopatologia, Zysk i S-ka, Poznań 2003.

Sternberg R.J., Human abilities: An information-processing approach, "Developmental Psychology" 1985, nr 24.

http:/ / michalpasterski.pl/2014/04/13-bledow-polskiego-systemu-edukacji [6.04. 2015].

16 "Gazeta Wyborcza” z 15 maja 2015 r. 